\title{
Job Quality In The Micro And Small Business Sector In Ethiopia: Evidence From Firm-Level Data
}

Berihu Assefa Gebrehiwot ( $\square$ berihuua86@gmail.com )

Ethiopian Development Research Institute (EDRI) https://orcid.org/0000-0002-1999-045X

\section{Research Article}

Keywords: job quality, entrepreneur, Ethiopia, manufacturing, MSE

Posted Date: November 12th, 2021

DOI: https://doi.org/10.21203/rs.3.rs-1046316/v1

License: (c) (1) This work is licensed under a Creative Commons Attribution 4.0 International License. Read Full License 


\section{Abstract}

Using a large dataset from the 10 largest cities in Ethiopia, this paper studies what entrepreneurial characteristics and attributes contribute to quality job creation in the micro and small enterprises (MSE) sector. We measure job quality in two ways - i) using wage and contract, and ii) health and occupational safety variables. We find that micro and small enterprises that create quality jobs tend to be operated by highly educated and experienced entrepreneurs. This highlights the role of human capital in quality job creation and poverty reduction. Further, we find that micro and small enterprises that create quality jobs tend to be larger in size and managed by professionally recruited managers.

\section{Introduction}

Poverty is still unacceptably high in the developing world (Chen \& Ravallion, 2010; WB, 2016). According to the World Bank's most recent report (WB, 2016) nearly 767 million people lived on less than $\$ 1.90$ a day in 2013, down from 1.85 billion in 1990. The major reason for the high poverty rate is the lack of access to decent work. That is, greater numbers of people are not able to lift themselves out of poverty despite the fact that they are working (Somavia, 1999). Vulnerable and informal jobs still constitute the bulk of employment available for many job seeking people in the developing world and in most cases, these jobs entail low pay, limited job security, and poor working conditions.

Poverty reduction through job creation by micro, small and medium-sized enterprises is the most commonly advocated and implemented strategy in many developing countries. Micro, small and medium-sized enterprises play a major role in the job creation process, which was empirically attested by studies such as Ayyagari, Demirguc-Kunt, \& Maksimovic (2011) and Deijl, de Kok, \& Essen (2013). This shows that the MSE sector commands a large share of employment in most countries, irrespective of income level or location. But the share is particularly high in developing countries. According to these studies, the median share of employment of the MSE sector is 67 percent. Given its importance for job creation, governments and non-government organizations provide multifaceted support programs for this sector through their MSE policies. However, the creation of new jobs is in itself not sufficient (ILO, 2015). Whether the new job lifts the people employed out of poverty or not is a major issue that has great implications on poverty reduction strategies. Poverty will only be reduced to the extent that earnings are sufficient to cover basic necessities. A joint study by the International Monetary Fund (IMF) and International Labour Organization (ILO) indicates that the majority of current jobs in developing countries, most of which come from the micro and small sectors, do not lift people out of poverty (IMF-ILO, 2010). There is a growing recognition that the effectiveness of poverty reduction strategies also lie on their added focus on quality of jobs beyond the immediate and conventional quantity aspect (ILO, 2015) .

Whether micro, small and medium enterprises create more jobs relative to large enterprises or not have been widely discussed (Ayyagari, Demirguc-Kunt, \& Maksimovic, 2011). However, to the best of our knowledge, whether the new jobs these enterprises create are of quality jobs and what drives quality job creation is less explored. Existing empirical works use worker data to study what workers value most in a job (Cazes, Hijzen, \& Saintmartin, 2015; De Bustillo R. M., FernándezMacías, Antón, \& Esteve, 2011a; Leschke \& Watt, 2008). In most of these empirical studies, the standard approach is to examine whether a job constitutes some of the qualities that workers value in a job such as better wages, job security and physical working conditions from a workers perspective. Such approaches require data on the different aspects of job quality and how much workers value them. Our question and approach is different in the sense that we flip the problem and approach it from the employers' side. We know from the existing literature the aspects of a good job, but what we don't know is who creates good jobs.

In the context of developing countries, MSE enterprises and their owners are important job creators and tend to be diverse in nature (Ayyagari, Demirguc-Kunt, \& Maksimovic, 2011). Given this, we think that it is quite crucial to explore the MSE sector in terms of the quality of jobs the sector creates. In view of this, our objective in this paper is to (i) document to what extent MSEs in Ethiopia create quality jobs (ii) explore the drivers of variation in creating quality employment within the MSES. In

Page $2 / 22$ 
doing so, we carefully study what entrepreneurial and enterprises attributes and strategies drive quality job creation in the Ethiopian MSE sector using a newly collected large dataset.

Our findings show that micro and small enterprises that create productive (quality) jobs tend to be operated by highly educated and experienced entrepreneurs. This finding interestingly highlights the role of human capital in the creation of quality jobs. We also find that micro and small enterprises that create productive (quality) jobs tend to be larger in size and are managed professionally by recruited managers.

The rest of the paper proceeds as follows. Section two presents a review of the conceptual and empirical literature in relation to job quality and poverty. Section three discusses the methodology, including the empirical strategy adopted for estimation and the data requirements. Section four presents and discusses the results of both the descriptive and regression analysis. Finally, section five concludes by providing some policy implications.

${ }^{1}$ According to the ILO (2013), decent work involves opportunities for work that is productive and delivers a fair income, security in the workplace and better prospects for personal development and social integration.

\section{Review Of Related Literature}

Traditionally, the most common measure of job quality has been the wage level (Erhel \& Guergoat-Larivière, 2010). But recent literature proposes additional various dimensions to the definition of job quality (Layard, 2005; Clark, 2001; De Bustillo R. M., Fernández-Macías, Antón, \& Esteve, 2011a; Hauff \& Kirchner, 2014). As a result, there is no one common definition of job quality in the literature. The existing literature can broadly be classified into three major categories.

(a) Subjective approaches - using the framework of the "economics of happiness" the job quality approach considers workers' points of view or perceptions through the development of surveys into job satisfaction and workers' well-being (Layard, 2005; Brown, Charlwood, Forde, \& Spencer, 2007).

(b) Objective approaches - this approach identifies several objective measures of job quality such as pay, autonomy, job intensity, job security, physical working conditions, health, learning and promotion prospects (Amossé \& Kalugina, 2010; Crespo, Simoes, \& Pinto, 2017; Westover, 2012; Davoine, Erhel, \& Guergoat-Lariviere, 2008; Erhel \& Guergoat-Larivière, 2010; Crespo, Simoes, \& Pinto, 2017; Tangian, 2009; Holman, 2013).

(c) Combination of both subjective and objective approaches - this is a more dominant approach combining both approaches (Kalleberg, Reskin, \& Hudson, 2000; Green, 2006).

Recognizing the heterogeneity of both jobs and workers, most of these studies use worker-level data to understand what explains variations in job quality. The existing literature tries to answer what key worker characteristics (such as sex, education, age, nationality and employment status) determine job quality (Muhlau, 2011; Jovanovic, 1979). To the best of our knowledge, there is little evidence on what entrepreneurial characteristics determine job quality. The MSE sector is quite diverse in terms of the amount and quality of jobs that it creates (See the literature on gazelles, e.g., Birch and Medoff, 1994; Picot and Dupuy, 1998; Schreyer, 2000; Littunen and Tohmo, 2003; Acs and Mueller, 2008; Hölzl, 2008; Henrekson and Dan Johansson, 2010). This warrants for a systematic study to explain what entrepreneurial attributes and characteristics drive job quality. To this end, our objective in this study is to understand the quality of jobs in the Ethiopian MSE sector and what entrepreneurial characteristics drive them.

We think that this question is not just important from academic point of view but it is also policy relevant. Most government's policy in the developing world seems to focus on the amount of jobs. In the context of Ethiopia, where our data is from, this can be inferred from its MSE support program which is extended to all MSE enterprises regardless of their growth orientation and the quality of jobs they create (FeMSEDA, 2011). However, MSE support programs could be more targeted to achieve both quantity and quality. We think that this study can contribute to better policy making and devising a 
more differentiated support programs by identifying the key entrepreneurial qualities, characteristics and strategies that drive productive job creation.

So, given this gap in the literature and the broader objectives and research questions set above, we specifically postulate and test the following two hypotheses:

\section{Hypothesis 1}

Enterprises that create quality jobs tend to be operated by highly educated and experienced entrepreneurs.

\section{Hypothesis 2}

Enterprises that create quality jobs tend to operate on larger scale than others, and are managed professionally (by recruited managers rather than by family members).

We think that our research work contributes to literature and policy in two ways:

(a) In terms of policy, MSE support programs in Ethiopia do not take into account the diverse nature of the sector. This kind of support program does not create the necessary incentives for enterprises to create productive jobs. The system seems to reward quantity and disregards quality. This will have its own implications in reducing poverty, especially in reducing the number of working poor. We think that our study would support first in bringing this issue to the attention of policy makers and second by identifying the key entrepreneurial qualities and strategies that help and drive productive job employment creation.

(b) In terms of literature, we hope that our study contributes in at least two ways: first, since the existing literature is far from having a reasonably common concept and measurement of job quality and comparable data for all countries, existing studies tend to be country or region specific. Thus the comparability and external validity of their findings is severely limited. In this regard, more country studies such as ours would help in enriching the existing literature and strengthening the external validity of the existing studies in the same area. Second, unlike most literature, we use firm-level data and approach. While most studies use worker-level data to explain individual level job quality, we use entrepreneur and enterprise characteristics and attributes to explain firm level job quality in the MSE sector.

\section{Methodology}

\subsection{Data}

Our data comes from a large representative sample survey of microenterprises and a census of small businesses in the 10 largest cities in Ethiopia - Addis Ababa, Mekelle, Bahir Dar, Dire Dawa, Adama, Dessie, Gonder, Hawassa and Jigjiga. Since Addis Ababa is a big city with a high concentration of MSE, the 10 sub cities within Addis Ababa are considered as 10 separate strata, using a sampling weight drawn from the population distribution to assign the sample size for each of the 10 sub cities in the city. From each sub city, a simple random sampling technique was used to draw the sample of micro enterprises. The population frame for these enterprises in Addis Ababa is created by combining three separate administrative lists compiled by the Bureau of Labor and Social Affairs, the Addis Ababa Trade and Industry Bureau and the Addis Ababa Urban Job Creation and Food Security Agency (formerly the Addis Ababa Micro and Small Enterprise Development Agency). As shown in Table 1, our final sampling frame for Addis Ababa constitutes a total of 16004 micro and small manufacturing enterprises. From this, 3298 of them were small while the remaining 12706 were microenterprises. While we conducted census for the small enterprises, we sampled 1195 micro enterprises from the 10 sub-cities of Addis Ababa using stratified random sampling technique. 
Table 1

Sampling Distribution of MSEs in Addis Ababa

\begin{tabular}{|lllll|}
\hline Sub cities & \multicolumn{3}{l}{ Population } & Surveyed \\
\cline { 2 - 5 } & Small & Micro & Small (census) & Micro (sample) \\
\hline Addis Ketema & 373 & 1090 & 373 & 141 \\
\hline Akaki Kaliti & 406 & 1177 & 406 & 86 \\
\hline Arada & 229 & 739 & 229 & 58 \\
\hline Bole & 361 & 1791 & 361 & 162 \\
\hline Gulele & 298 & 1144 & 298 & 100 \\
\hline Kirkos & 191 & 840 & 191 & 76 \\
\hline Kolfie & 229 & 2426 & 229 & 247 \\
\hline Lideta & 125 & 520 & 125 & 59 \\
\hline Nifas Silk & 738 & 1626 & 738 & 121 \\
\hline Yeka & 348 & 1353 & 348 & 145 \\
\hline All & 3298 & 12706 & 3298 & 1195 \\
\hline Source: ESBDE Baseline Survey, 2017 & \\
\hline
\end{tabular}

The frame used for the nine regional cities was also based on largely a similar approach with that of Addis Ababa. The only exception was that there was no administrative data at the regional bureaus of Labor and Social Affairs and thus the sampling frame was constructed using the Regional Micro and Small Enterprise Development Agencies (ReMSEDA) and the trade and industry bureau of each region. We used cities to stratify the sample and the sample size in each city was determined using the population distribution of these enterprises as a sampling weight. As indicated in Table 2, we conducted a census of the small firms (total 1566) and survey of a randomly selected 2115 micro enterprise firms in the nine regional cities. 
Table 2

Sampling distribution of MSEs in the Nine Major Regional Cities

\begin{tabular}{|lllll|}
\hline \multirow{2}{*}{ Cities } & \multicolumn{2}{l}{ Population } & Surveyed \\
\cline { 2 - 5 } & Small & Micro & Small (census) & Micro (sample) \\
\hline Adama & 121 & 531 & 121 & 140 \\
\hline Bahir Dar & 252 & 948 & 252 & 314 \\
\hline Dessie & 89 & 384 & 89 & 147 \\
\hline Dire Dawa & 126 & 447 & 126 & 118 \\
\hline Gondar & 126 & 737 & 126 & 211 \\
\hline Hawassa & 316 & 806 & 316 & 143 \\
\hline Jigjiga & 60 & 120 & 60 & 44 \\
\hline Jimma & 146 & 480 & 146 & 148 \\
\hline Mekele & 330 & 2449 & 330 & 850 \\
\hline All & 1,566 & 6902 & 1,566 & 2,115 \\
\hline Source: ESBDE Baseline Survey, 2017 & \\
\hline
\end{tabular}

We then conducted face-to-face interviews from December 2016 to June 2017 by implementing a survey instrument that contains a rich set of questions on demographic characteristic of the entrepreneur, business profile, credit history, saving culture, number of workers, capital stock, cognitive ability, risk and time preference. The survey instrument was designed in an electronic version (CSPro) to collect the data using a Computer-Assisted Personal Interview (CAPI) system. The CAPI technology helped us produce better quality data by minimizing coding and manual errors and shorted the data collection time.

\subsection{Empirical strategy}

The existing body of literature explains job quality as a function of two groups of determinants: socio-economic characteristics of workers and characteristics of firms (Crespo, Simoes, \& Pinto, 2017; Green, 2006; Hauff \& Kirchner, 2014). In this paper, we are more interested in studying what entrepreneurial and enterprise characteristics and attributes contribute to quality job creation. In other words, we aim to examine how and in what ways firms that create productive jobs differ in their characteristics and attributes from those that create less quality jobs. We measure job quality by a set of variables: (i) average pay, (ii) nature of employment contract firms enter with their workers, and (iii) physical working conditions. We measure average pay by the average wage enterprises pay for their production workers. Employment contract is defined by a contract dummy variable which is 1 if the enterprises offer written contracts to their workers and 0 otherwise. We can alternatively define it by either the proportion of workers that gets offered written contracts or the proportion of permanent employees in a given enterprise. On the other hand, we define and measure physical working conditions by a set of health and occupational safety variables: (a) a dummy variable called PPCE, which is equal to 1 if the enterprise provides its workers with all the necessary personal protective clothing and equipment and 0 otherwise; (b) a dummy variable called occupational safety training, which is equal to 1 if the enterprise effectively trains its workers on occupational safety issues and 0 otherwise; (c) number of work-related accidents in the enterprise.

Based on hypothesis 1, MSE enterprises that create productive (quality) jobs tend to be operated by educated and experienced entrepreneurs. To capture the effects of education, we use three indicators: (a) years of schooling, measured by the total number of years of schooling of the entrepreneur; (b) vocational training, a dummy variable equal to 1 if the entrepreneur attended vocational school and 0 otherwise; and (c) international language proficiency, which is measured a dummy variable equal to 1 if the entrepreneur speaks English well and 0 otherwise. It is assumed that for an 
owner/manager who aspires to grow and interact with global customers, speaking English constitutes part of his human capital aspect. On the other hand, managerial experience is captured by years of operation or number of years of business ownership by the entrepreneur.

Likewise, based on hypothesis 2, we assert that larger enterprises tend to create better quality jobs. Enterprise size is measured by number of workers, and enters the regression as dummy variable, where we have three size categories: Micro ( 1 to 5 employees), small (6 to 30 employees) and medium (more than 30 employees).

So to test our hypotheses, we regress the dependent variables (i) to (iii) on entrepreneur and enterprise characteristics, such as education, management experience and other exogenous variables. If we denote the dependent variables as $Y_{i}$ with subscript $\mathrm{i}$ indicating enterprises, and $\mathrm{X}_{\mathrm{i}}$ as explanatory variables, the regression equation can be written as:

$$
\boldsymbol{Y}_{i}=\boldsymbol{X}_{i} \boldsymbol{\alpha}_{i}+\varepsilon_{i}
$$

Where $\alpha_{i}$ is a vector of parameters to be estimated and $\epsilon_{i}$ is an error term.

While the wage and number of work-related accidents equations are estimated using OLS method, the equations explaining the proportion of workers with written contract and/or the proportion of permanent workers in an enterprise are estimated with the two limit Tobit estimator because the data on these variables are censored at 0 and 1 (Long, 1997). On the other hand, the categorical dependent variables (i.e., contract dummy, occupational safety training, and PPCE dummies) are estimates using the logistic regression method.

Below we discuss the two potential categories of determinants of job quality: entrepreneur and firm characteristics.

(i) Entrepreneur related characteristics

Age: age is associated with experience, especially non-managerial (Mumford \& Smith, 2004); and experience forms part of human capital of the owner (Becker, 1962). The link with job quality is that MSE enterprises creating productive jobs tend to be operated by experienced owners.

Gender: evidence show that men and women have different risk attitudes and such attitudes tend to be reflected in their decisions and actions (Stier \& Yaish, 2014). Following these differences in risk aversions between men and women, several studies found evidence of variations in relation to working conditions where men tend to focus on creating competitive environments and paying higher wages and women tend to create better working conditions and pay lower wages (Stier \& Yaish, 2014; Levanon, England, \& Allison, 2009). The gender-related issue may also be associated with time-use and effort dilution of female entrepreneurs as they often have to juggle between the business and household. Further, social attitude and norms put further strain on female operated businesses.

Education: ever since the seminal work of Becker (1962), the role of education has been widely researched. In relation to job quality, we hypothesize that better educated entrepreneurs tend to create better quality jobs. MSEs with highly educated entrepreneurs tend to produce more expensive products. And expensive products tend to have better qualities. Highly educated and experienced workers are more likely to produce better quality products. And enterprises that offer better quality jobs are highly likely to attract better skilled and experienced people.

Employment experience in the formal sector: whether the owner was self-employed from the beginning or s/he has worked as a wage-earner in the formal sector has implications on the owner's views and behavior towards workers and working conditions. His experience as a wage-earner may help the owner to better connect with workers and this might contribute towards improving the productivity of employment in the form of better relations and workers participation, for example, which are considered as dimensions of job quality. 
Self-employment experience - whether an entrepreneur has a long spell of experience of self-employment is a strong indicator of business ownership and management experience. The advantages of self-employment would arise from the direct exposure, hands-on managerial practice and learning by doing effects, which cumulatively build the managerial capacity of entrepreneurs.

\section{(ii) Firm characteristics}

Ownership form

the current form of ownership of the firm is considered as a potential determinant of job quality. Different forms of ownership vary in terms of wage and other working conditions. For example, cooperatives tend to perform less than noncooperatives. This is so because the former tends to suffer from organizational and managerial problems ( (Assefa, Zerfu, \& Tekle, 2014).

\section{Firm size}

firm size is another important determinant of job quality. There is considerable literature on the positive relationship between firm size and job quality (Brown \& Medoff, 1989; Oi \& Idson, 1999). Contract administration has administrative costs. The average contract administration cost tends to be lower for larger firms. Consequently it is relatively easier for larger firms to offer written contracts.

\section{Results}

\subsection{Descriptive results analysis}

The total sample considered in the study is 8174 enterprises. Table 3 presents the composition of the sample in terms of basic characteristics of the entrepreneur and enterprises. 
Table 3

Sample composition and explanatory variables

\begin{tabular}{|c|c|c|}
\hline Variables & Number & Percentage \\
\hline \multicolumn{3}{|c|}{ Owner (entrepreneur) characteristics } \\
\hline \multicolumn{3}{|l|}{ Gender } \\
\hline Male & 6,618 & 81.08 \\
\hline Female & 1,544 & 18.92 \\
\hline \multicolumn{3}{|l|}{ Age group } \\
\hline $18-30$ & 2,084 & 25.5 \\
\hline $31-50$ & 5,199 & 63.6 \\
\hline $51-65$ & 722 & 8.83 \\
\hline$>65$ & 169 & 2.07 \\
\hline \multicolumn{3}{|l|}{ Marital status } \\
\hline Single & 1,706 & 20.91 \\
\hline Married & 6,199 & 75.97 \\
\hline Divorced & 113 & 1.38 \\
\hline Separated & 42 & 0.51 \\
\hline Widowed & 100 & 1.23 \\
\hline \multicolumn{3}{|l|}{ Level of education } \\
\hline No education & 142 & 1.74 \\
\hline Read \& write (Basic) & 581 & 7.13 \\
\hline Primary education & 1,330 & 16.31 \\
\hline Secondary education & 2,605 & 31.95 \\
\hline Preparatory education & 347 & 4.26 \\
\hline TVET completed & 1,383 & 16.96 \\
\hline Diploma & 758 & 9.3 \\
\hline Bachelor and above & 1,007 & 12.35 \\
\hline \multicolumn{3}{|c|}{ Business ownership experience } \\
\hline No experience & 58 & 0.71 \\
\hline $1-15$ years & 7,311 & 89.44 \\
\hline $16-30$ years & 669 & 8.18 \\
\hline $31-45$ years & 95 & 1.16 \\
\hline$>45$ years & 41 & 0.5 \\
\hline Firm characteristics & & \\
\hline
\end{tabular}

Source: ESBDE Baseline Survey, 2017 


\begin{tabular}{|c|c|c|}
\hline Variables & Number & Percentage \\
\hline \multicolumn{3}{|l|}{ Ownership sector } \\
\hline Public owned & 3 & 0.04 \\
\hline Private limited & 921 & 11.27 \\
\hline Share company & 268 & 3.28 \\
\hline Partnership & 1,130 & 13.82 \\
\hline Sole proprietorship & 4,662 & 57.03 \\
\hline Cooperative & 1,182 & 14.46 \\
\hline others & 8 & 0.1 \\
\hline \multicolumn{3}{|l|}{ Firm size } \\
\hline Micro & 3,310 & 40.49 \\
\hline Small & 4,553 & 55.7 \\
\hline Medium & 311 & 3.8 \\
\hline \multicolumn{3}{|l|}{ Firm age category } \\
\hline $2-4$ years & 4016 & 49.1 \\
\hline $5-9$ years & 2605 & 31.9 \\
\hline$>9$ years & 1548 & 19.0 \\
\hline \multicolumn{3}{|l|}{ Economic sub-sector } \\
\hline Food and beverages & 1,648 & 20.16 \\
\hline Textiles & 328 & 4.01 \\
\hline Garments & 769 & 9.41 \\
\hline Chemicals & 102 & 1.25 \\
\hline Plastics and rubber & 98 & 1.2 \\
\hline Nonmetallic mineral products & 554 & 6.78 \\
\hline Metal working workshop & 1,635 & 20 \\
\hline Printing & 322 & 3.94 \\
\hline Machinery and equipment & 60 & 0.73 \\
\hline Electronics & 27 & 0.33 \\
\hline Furniture and wood working & 1,882 & 23.02 \\
\hline Leather and Leather products & 296 & 3.62 \\
\hline Blocket and other construction inputs & 367 & 4.49 \\
\hline Metal and Woodwork & 44 & 0.54 \\
\hline Other & 42 & 0.51 \\
\hline
\end{tabular}

Source: ESBDE Baseline Survey, 2017

Page 10/22 


\begin{tabular}{|lll|}
\hline Variables & Number & Percentage \\
\hline Enterprise location & & \\
\hline Adama & 261 & 3.19 \\
\hline Addis Ababa & 4,493 & 54.97 \\
\hline Bahir Dar & 566 & 6.92 \\
\hline Dessie & 236 & 2.89 \\
\hline Dire Dawa & 244 & 2.99 \\
\hline Gondar & 337 & 4.12 \\
\hline Hawassa & 459 & 5.62 \\
\hline Jigjiga & 104 & 1.27 \\
\hline Jimma & 294 & 3.6 \\
\hline Mekelle & 1,180 & 14.44 \\
\hline Source: ESBDE Baseline Survey, 2017 & & \\
\hline
\end{tabular}

As indicated in Table 3, in terms of gender, our sample comprises mostly male entrepreneurs (81 percent). Most of the entrepreneurs (64 percent) are between the ages of 31 and 50 years; are married (76 percent); have completed TVET and above (38 percent, while 32 percent completed secondary education); and have less than 16 years of business ownership or self-employment experience (89 percent). Likewise, Table 3 also presents enterprise characteristics, where we find that most enterprises' form of ownership or legal status is sole proprietorship (57 percent); large number of enterprises are in the small size category, employing 6 to 30 workers (55 percent versus 40 percent in the micro size category). About 55 percent of the enterprises are also located in Addis Ababa. In terms of subsector, our sample firms seem to be equally distributed among the various subsectors, except the furniture and food and beverage subsectors which seem to be overrepresented. 
Table 4

Job quality (productivity) indicators by entrepreneurs' highest completed level of education

\begin{tabular}{|c|c|c|c|c|c|c|c|}
\hline \multirow{2}{*}{$\begin{array}{l}\text { Highest } \\
\text { level of } \\
\text { education } \\
\text { completed }\end{array}$} & \multicolumn{7}{|c|}{ Productive (quality) employment indicators } \\
\hline & $\begin{array}{l}\text { Average } \\
\text { monthly } \\
\text { earning }\end{array}$ & $\begin{array}{l}\text { Offers } \\
\text { written } \\
\text { contract } \\
(\%)\end{array}$ & $\begin{array}{l}\text { What } \\
\text { Percentage of } \\
\text { your workers } \\
\text { have written } \\
\text { contract? (\%) }\end{array}$ & $\begin{array}{l}\text { Proportion } \\
\text { of } \\
\text { permanent } \\
\text { workers } \\
(\%)\end{array}$ & $\begin{array}{l}\text { Average number } \\
\text { of work related } \\
\text { accidents in the } \\
\text { last six months }\end{array}$ & $\begin{array}{l}\text { Provide } \\
\text { all } \\
\text { necessary } \\
\text { PPCE (\%) }\end{array}$ & $\begin{array}{l}\text { Occupational } \\
\text { Safety } \\
\text { training (\%) }\end{array}$ \\
\hline $\begin{array}{l}\text { No } \\
\text { education }\end{array}$ & 1039 & 5.6 & 64 & 8 & 0.05 & 49.3 & 13.89 \\
\hline $\begin{array}{l}\text { Read and } \\
\text { write } \\
\text { (basic) }\end{array}$ & 1557 & 4.8 & 68 & 6 & 0.16 & 57.8 & 6 \\
\hline $\begin{array}{l}\text { Primary } \\
\text { education }\end{array}$ & 1661 & 8.1 & 62.1 & 9 & 0.13 & 57.1 & 11.03 \\
\hline $\begin{array}{l}\text { Secondary } \\
\text { education }\end{array}$ & 1921 & 14.3 & 61.6 & 12 & 0.15 & 61.8 & 14.51 \\
\hline $\begin{array}{l}\text { Preparatory } \\
\text { education }\end{array}$ & 1823 & 11.9 & 71 & 9 & 0.34 & 82.6 & 18.46 \\
\hline $\begin{array}{l}\text { TVET } \\
\text { completed }\end{array}$ & 2158 & 14.1 & 63.4 & 13 & 0.19 & 67.3 & 15.35 \\
\hline Diploma & 2333 & 26.3 & 68.3 & 24 & 0.13 & 74.0 & 20.38 \\
\hline $\begin{array}{l}\text { Bachelor } \\
\text { and above }\end{array}$ & 2244 & 36.8 & 74.6 & 27 & 0.16 & 74.8 & 29.17 \\
\hline All & 1954 & 16.4 & 67.1 & 14 & 0.16 & 65.1 & 16.33 \\
\hline
\end{tabular}

From Table 4, we see that human capital measured by number of years of formal schooling by the entrepreneur, completion of vocational training and the ability to speak English language are highly related to all the indicators of job quality. Number of years of schooling is strongly and positively related to wage, existence of written contract or the proportion of permanent workers, and the provision of all the necessary occupational safety measures. Especially, vocationally trained entrepreneurs tend to provide occupational safety measures such as providing training to their workers on occupational safety measures and providing all the necessary personal protective clothing and equipment (PPCE).

Table 5

Productive (quality) job indicators by years of operation of enterprises

\begin{tabular}{|c|c|c|c|c|c|c|c|}
\hline \multirow{2}{*}{$\begin{array}{l}\text { Age } \\
\text { category } \\
\text { of } \\
\text { enterprises }\end{array}$} & \multicolumn{7}{|c|}{ Productive (quality) employment indicators by years of operation of the enterprises } \\
\hline & $\begin{array}{l}\text { Average } \\
\text { monthly } \\
\text { earning }\end{array}$ & $\begin{array}{l}\text { Offers } \\
\text { written } \\
\text { contract } \\
(\%)\end{array}$ & $\begin{array}{l}\text { What Percentage } \\
\text { of your workers } \\
\text { have written } \\
\text { contract? (\%) }\end{array}$ & $\begin{array}{l}\text { Proportion } \\
\text { of } \\
\text { permanent } \\
\text { workers (\%) }\end{array}$ & $\begin{array}{l}\text { Average work- } \\
\text { related accidents } \\
\text { in the last six } \\
\text { months }\end{array}$ & $\begin{array}{l}\text { Offers } \\
\text { PPCE } \\
(\%)\end{array}$ & $\begin{array}{l}\text { Occupational } \\
\text { safety } \\
\text { training (\%) }\end{array}$ \\
\hline $2-4$ years & 1781.5 & 12.4 & 65.9 & 10 & 0.15 & 62.2 & 14.7 \\
\hline $5-9$ years & 2056.3 & 17.7 & 64.5 & 20 & 0.21 & 66 & 15.7 \\
\hline$>9$ years & 2237.6 & 24.6 & 71.9 & 20 & 0.15 & 71.2 & 21.9 \\
\hline All & 1956.2 & 16.4 & 67.2 & 10 & 0.17 & 65.2 & 7.8 \\
\hline
\end{tabular}


Likewise, as indicated in Table 5, years of management experience, measured by years of operation of the firm is also positively correlated with higher wages, contract security and occupational safety measures. All the results presented in Table 4 and Table 5 confirm our first hypothesis, which postulates that enterprises that create quality or productive employment tend to be operated by highly educated and experienced entrepreneurs.

The results of Table 6 confirm the validity of our second hypothesis, which claims whether size of enterprises drives quality job creation. Clearly, enterprise size is strongly related to the various job quality measures, with larger size firms paying higher wages, are more likely to offer written contracts and occupational safety measures. The fact that size of firms is a strong predictor of productive employment might be related the resource base theory ( (Barney, 1996).

Table 6: Job quality (productivity) indicators by enterprise size

\begin{tabular}{|c|c|c|c|c|c|c|c|c|c|c|}
\hline \multirow{3}{*}{$\begin{array}{l}\text { Size } \\
\text { category }\end{array}$} & \multicolumn{10}{|c|}{ Productive (quality) employment indicators } \\
\hline & \multirow[t]{2}{*}{$\begin{array}{l}\text { Average } \\
\text { monthly } \\
\text { earning }\end{array}$} & \multicolumn{2}{|c|}{$\begin{array}{l}\text { Offers written } \\
\text { contract? (Yes) }\end{array}$} & \multirow{2}{*}{$\begin{array}{l}\text { What } \\
\text { Percentage } \\
\text { of your } \\
\text { workers } \\
\text { have } \\
\text { written } \\
\text { contract? } \\
\text { (\%) }\end{array}$} & \multirow{2}{*}{$\begin{array}{l}\text { Proportion } \\
\text { of } \\
\text { permanent } \\
\text { workers } \\
\text { (\%) }\end{array}$} & \multirow{2}{*}{$\begin{array}{l}\text { Average } \\
\text { work } \\
\text { related } \\
\text { accidents } \\
\text { in the } \\
\text { last six } \\
\text { months }\end{array}$} & \multicolumn{2}{|c|}{$\begin{array}{l}\text { Offers PPCE? } \\
\text { (Yes) }\end{array}$} & \multicolumn{2}{|c|}{$\begin{array}{l}\text { Occupational } \\
\text { safety training? } \\
\text { (Yes) }\end{array}$} \\
\hline & & Number & $\%$ & & & & Number & $\%$ & Number & $\%$ \\
\hline Micro & 1604 & 174 & 5.6 & 67.0 & 8 & 0.15 & 200 & 12.6 & 1906 & 58.8 \\
\hline Small & 2133 & 920 & 21.0 & 65.2 & 17 & 0.17 & 369 & 17.5 & 3065 & 68.7 \\
\hline Medium & 2945 & 188 & 61.0 & 76.9 & 43 & 0.19 & 60 & 38.0 & 244 & 80.0 \\
\hline All & 1956.4 & 1284 & 16.4 & 67.2 & 14 & 0.16 & 629 & 16.3 & 5215 & 65.2 \\
\hline
\end{tabular}

Source: ESBDE Baseline Survey, 2017

In a similar manner, we also presented the effect of other key characteristics of entrepreneurs and enterprises in Table 7, Table 8, and Table 9. An additional finding in relation to enterprise characteristics is that enterprise location, measured by whether the enterprise is located in Addis or not (see Table 7) is positively related with many of the job quality indicators. Enterprises that are located in Addis Ababa tend to offer higher wages, written contracts and better occupational safety measures. This could be related many things such as better access to infrastructures, market centers, and supply conditions.

Table 7

Productive (quality) indicators by enterprise location

\begin{tabular}{|llllllll|}
\hline $\begin{array}{l}\text { Location } \\
\text { of } \\
\text { enterprises }\end{array}$ & \multicolumn{6}{l}{ Productive (quality) indicators by enterprise location } \\
\cline { 2 - 7 } & $\begin{array}{l}\text { Average } \\
\text { monthly } \\
\text { earning }\end{array}$ & $\begin{array}{l}\text { Offers } \\
\text { written } \\
\text { contract } \\
\text { (\%) }\end{array}$ & $\begin{array}{l}\text { What Percentage } \\
\text { of your workers } \\
\text { have written } \\
\text { contract? (\%) }\end{array}$ & $\begin{array}{l}\text { Proportion } \\
\text { of } \\
\text { permanent } \\
\text { workers (\%) }\end{array}$ & $\begin{array}{l}\text { Average work } \\
\text { related accidents } \\
\text { in the last six } \\
\text { months }\end{array}$ & $\begin{array}{l}\text { Offers } \\
\text { PPCE } \\
\text { (\%) }\end{array}$ & $\begin{array}{l}\text { Occupational } \\
\text { safety } \\
\text { training (\%) }\end{array}$ \\
\hline $\begin{array}{l}\text { Addis } \\
\text { Ababa }\end{array}$ & 2150 & 26.2 & 68.2 & 24 & 0.13 & 72 & 20 \\
\hline $\begin{array}{l}\text { Other } \\
\text { cities }\end{array}$ & 1720 & 4.4 & 59.3 & 3 & 0.20 & 57 & 13 \\
\hline All & 1956 & 16.4 & 67.2 & 14 & 0.17 & 65 & 16 \\
\hline
\end{tabular}


Table 8

Productive (quality) job indicators by sex of entrepreneurs

\begin{tabular}{|llllllll|}
\hline Sex & \multicolumn{3}{l}{ Productive (quality) job indicators by sex of entrepreneur } & & \\
\cline { 2 - 6 } & $\begin{array}{l}\text { Average } \\
\text { monthly } \\
\text { earning }\end{array}$ & $\begin{array}{l}\text { Offers } \\
\text { written } \\
\text { contract } \\
\text { (\%) }\end{array}$ & $\begin{array}{l}\text { What Percentage of } \\
\text { your workers have } \\
\text { written contract? } \\
(\%)\end{array}$ & $\begin{array}{l}\text { Proportion } \\
\text { of } \\
\text { permanent } \\
\text { workers (\%) }\end{array}$ & $\begin{array}{l}\text { Average work } \\
\text { related accidents } \\
\text { in the last six } \\
\text { months }\end{array}$ & $\begin{array}{l}\text { Provide } \\
\text { PPCE } \\
\text { (\%) }\end{array}$ & $\begin{array}{l}\text { Occupational } \\
\text { safety } \\
\text { training? (\%) }\end{array}$ \\
\hline Male & 2045 & 16.14 & 66.1 & 14 & 0.18 & 66.5 & 16.5 \\
\hline Female & 1563 & 17.37 & 71.3 & 16 & 0.09 & 59 & 15.5 \\
\hline All & 1954 & 16.37 & 67.1 & 15 & 0.165 & 65 & 16.3 \\
\hline
\end{tabular}

Table 9

Productive (quality) job indicators by age of entrepreneurs

\begin{tabular}{|c|c|c|c|c|c|c|c|}
\hline \multirow{2}{*}{$\begin{array}{l}\text { Age } \\
\text { class }\end{array}$} & \multicolumn{7}{|c|}{ Productive (quality) job indicators by age of entrepreneurs } \\
\hline & $\begin{array}{l}\text { Average } \\
\text { monthly } \\
\text { earning }\end{array}$ & $\begin{array}{l}\text { Offers } \\
\text { written } \\
\text { contract } \\
(\%)\end{array}$ & $\begin{array}{l}\text { What Percentage of } \\
\text { your workers have } \\
\text { written contract? (\%) }\end{array}$ & $\begin{array}{l}\text { Proportion of } \\
\text { permanent } \\
\text { workers (\%) }\end{array}$ & $\begin{array}{l}\text { Average work } \\
\text { related accidents } \\
\text { in the last six } \\
\text { months }\end{array}$ & $\begin{array}{l}\text { Offers } \\
\text { PPCE } \\
\text { (\%) }\end{array}$ & $\begin{array}{l}\text { Occupational } \\
\text { safety } \\
\text { training (\%) }\end{array}$ \\
\hline $\begin{array}{l}18- \\
30\end{array}$ & 1683 & 8.1 & 64.7 & 7 & 0.16 & 12.7 & 60.3 \\
\hline $\begin{array}{l}31- \\
50\end{array}$ & 2042 & 17.7 & 64.8 & 15 & 0.16 & 16.8 & 66.6 \\
\hline $\begin{array}{l}51- \\
65\end{array}$ & 2106 & 28.1 & 76 & 24 & 0.13 & 22.3 & 68.4 \\
\hline$>65$ & 2037 & 28.5 & 85.3 & 30 & 0.16 & 23.3 & 66.1 \\
\hline All & 1956 & 16.4 & 67.2 & 14 & 0.16 & 16.3 & 65.2 \\
\hline
\end{tabular}

Tables Table 8 andTable 9 also present more entrepreneur characteristics, among which age and sex are quite crucial. We see that both age and being male have a strong positive effect on productive employment creation.

\subsection{Estimation results analysis}

Our estimated regression results are presented in Table 10. While the estimated regression results for wage and contract dependent variables are presented in columns 1 to 4; the estimation results for health and occupational safety variables are presented in columns 5 to 7 . We find that human capital, measured by years of schooling and vocational training, shows positive and highly significant effect on wages. The ability to speak English, which can be taken as another aspect of human capital, also has positive and strong effects on wages. Especially the number of years of formal schooling tends to have a highly significant effect on all job quality indicators (see Table 10 columns 1 to 5). Similarly, entrepreneurs who have attended vocational training tend to pay higher wages and provide better health and occupational safety measures (see columns 1,5 and 6 ). These results confirm the validity of hypothesis 1 . Hypothesis 1 postulates that highly educated entrepreneurs aim to produce high quality products, which require employing better skilled and disciplined workers. And in 
order to attract high skilled workers, enterprises need to offer better quality jobs in the form of higher wages, better working conditions and occupational safety measures. 
Table 10

Estimated Regression Models for Key Job Quality Variables - Wage, Contract and Health and Occupational safety

\begin{tabular}{|c|c|c|c|c|c|c|}
\hline \multirow[t]{3}{*}{ VARIABLES } & \multicolumn{3}{|c|}{ Wage and contract variables } & \multicolumn{3}{|c|}{ Health and occupational safety variables } \\
\hline & In(wage) & $\begin{array}{l}\text { Written } \\
\text { contract } \\
\text { (binary) }\end{array}$ & $\begin{array}{l}\text { Permanent } \\
\text { workers } \\
\text { (Proportion) }\end{array}$ & $\begin{array}{l}\text { PPCE } \\
\text { (binary) }\end{array}$ & $\begin{array}{l}\text { Safety } \\
\text { training } \\
\text { (binary) }\end{array}$ & $\begin{array}{l}\text { In(number of work } \\
\text { related accidents) }\end{array}$ \\
\hline & OLS (1) & $\begin{array}{l}\text { Logistic } \\
\text { (2) }\end{array}$ & Tobit (4) & $\begin{array}{l}\text { Logistic } \\
\text { (5) }\end{array}$ & $\begin{array}{l}\text { Logistic } \\
\text { (6) }\end{array}$ & OLS (7) \\
\hline
\end{tabular}

\section{Entrepreneur characteristics \\ \& background}

\begin{tabular}{|c|c|c|c|c|c|c|}
\hline \multirow[t]{2}{*}{ Male } & $0.061^{\star \star *}$ & -0.113 & -0.020 & $0.133^{\star}$ & 0.107 & -0.023 \\
\hline & $(0.018)$ & $(0.102)$ & $(0.028)$ & $(0.070)$ & $(0.134)$ & $(0.078)$ \\
\hline \multirow[t]{2}{*}{ Age } & 0.010 ** & $0.069 * * *$ & $0.0199 * \star \star$ & $0.0280^{*}$ & -0.026 & 0.003 \\
\hline & $(0.004)$ & $(0.025)$ & $(0.007)$ & $(0.016)$ & $(0.027)$ & $(0.023)$ \\
\hline \multirow[t]{2}{*}{ Age square } & $-0.0002^{\star *}$ & $-0.0006^{* *}$ & $-0.0001 *$ & $-0.0003^{*}$ & 0.0004 & 0.00001 \\
\hline & $(0.00005)$ & $(0.0003)$ & $(0.0001)$ & $(0.0002)$ & $(0.0003)$ & $(0.0003)$ \\
\hline \multirow[t]{2}{*}{ Married } & $0.034^{\star \star}$ & 0.106 & 0.030 & 0.037 & -0.189 & -0.025 \\
\hline & $(0.016)$ & (0.101) & $(0.027)$ & $(0.065)$ & (0.119) & $(0.064)$ \\
\hline \multirow[t]{2}{*}{ Christian } & -0.024 & $-0.733^{\star}$ & 0.113 & -0.006 & -0.632 & 0.063 \\
\hline & $(0.088)$ & $(0.424)$ & $(0.133)$ & $(0.365)$ & $(0.498)$ & $(0.092)$ \\
\hline \multirow[t]{2}{*}{ Muslim } & -0.003 & $-0.837 \star$ & 0.140 & 0.167 & -0.185 & \\
\hline & $(0.089)$ & $(0.441)$ & $(0.136)$ & $(0.371)$ & $(0.510)$ & \\
\hline \multirow[t]{2}{*}{ Education (number of years) } & $0.006 * \star \star$ & $0.058 * \star \star$ & $0.016 * * *$ & $0.014^{\star *}$ & 0.009 & -0.002 \\
\hline & $(0.001)$ & $(0.014)$ & $(0.005)$ & $(0.006)$ & $(0.013)$ & $(0.005)$ \\
\hline \multirow[t]{2}{*}{ Had vocational training } & $0.059 * \star \star$ & $-0.176 * \star$ & -0.021 & $0.373^{\star \star \star}$ & $0.632 * \star \star$ & -0.019 \\
\hline & $(0.015)$ & $(0.086)$ & $(0.024)$ & $(0.062)$ & $(0.101)$ & $(0.052)$ \\
\hline \multirow[t]{2}{*}{ Speaks English } & $0.050 * \star \star$ & $0.545^{\star \star \star}$ & $0.109 * * \star$ & -0.069 & $0.377 * \star \star$ & -0.079 \\
\hline & $(0.017)$ & $(0.093)$ & $(0.028)$ & $(0.069)$ & $(0.116)$ & $(0.056)$ \\
\hline \multirow[t]{2}{*}{ Worked as wage worker } & 0.019 & 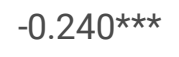 & $-0.074^{\star \star \star}$ & $0.294^{\star \star \star}$ & $-0.450 * \star \star$ & -0.007 \\
\hline & $(0.014)$ & $(0.081)$ & $(0.022)$ & $(0.054)$ & $(0.098)$ & $(0.050)$ \\
\hline \multirow{2}{*}{$\begin{array}{l}\text { Self-employment experience } \\
\text { (years) }\end{array}$} & 0.002 & $0.014 * \star$ & 0.002 & 0.001 & $0.032 * \star \star$ & -0.006 \\
\hline & $(0.001)$ & $(0.007)$ & $(0.002)$ & $(0.005)$ & $(0.008)$ & $(0.006)$ \\
\hline Father has business & $-0.103^{\star \star *}$ & 0.028 & $-0.119 \star \star \star$ & $0.135^{\star \star}$ & -0.030 & -0.040 \\
\hline
\end{tabular}

background

Notes (1): *** $p<0.01,{ }^{* *} p<0.05,{ }^{*} p<0.1$ are significance levels at $1,5 \& 10$ percent respectively. And numbers in parentheses are standard errors.

Notes (2): Coefficients for logistic regression are in log-odds units.

Source: ESBDE Baseline Survey, 2017 


\begin{tabular}{|c|c|c|c|c|c|c|}
\hline \multirow[t]{3}{*}{ VARIABLES } & \multicolumn{3}{|c|}{ Wage and contract variables } & \multicolumn{3}{|c|}{ Health and occupational safety variables } \\
\hline & In(wage) & $\begin{array}{l}\text { Written } \\
\text { contract } \\
\text { (binary) }\end{array}$ & $\begin{array}{l}\text { Permanent } \\
\text { workers } \\
\text { (Proportion) }\end{array}$ & $\begin{array}{l}\text { PPCE } \\
\text { (binary) }\end{array}$ & $\begin{array}{l}\text { Safety } \\
\text { training } \\
\text { (binary) }\end{array}$ & $\begin{array}{l}\text { In(number of work } \\
\text { related accidents) }\end{array}$ \\
\hline & OLS (1) & $\begin{array}{l}\text { Logistic } \\
(2)\end{array}$ & Tobit (4) & $\begin{array}{l}\text { Logistic } \\
(5)\end{array}$ & $\begin{array}{l}\text { Logistic } \\
(6)\end{array}$ & OLS (7) \\
\hline & $(0.015)$ & $(0.086)$ & $(0.023)$ & $(0.060)$ & $(0.108)$ & $(0.050)$ \\
\hline \multirow{2}{*}{$\begin{array}{l}\text { Number of siblings in similar } \\
\text { business }\end{array}$} & -0.001 & 0.008 & $-0.007 * \star$ & -0.006 & $-0.028 * \star$ & 0.026 \\
\hline & $(0.003)$ & $(0.019)$ & $(0.003)$ & $(0.012)$ & $(0.013)$ & $(0.024)$ \\
\hline \multicolumn{7}{|l|}{ Enterprise characteristics } \\
\hline \multirow[t]{2}{*}{ Firm age } & 0.002 & $0.019 * *$ & 0.002 & $0.011^{*}$ & -0.013 & 0.004 \\
\hline & $(0.002)$ & $(0.008)$ & $(0.002)$ & $(0.007)$ & $(0.010)$ & $(0.007)$ \\
\hline \multirow[t]{2}{*}{ Is cooperative } & -0.084 & 13.15 & -0.012 & -0.290 & 13.60 & -0.098 \\
\hline & $(0.200)$ & $(1,133)$ & $(0.435)$ & $(0.700)$ & $(817.0)$ & $(0.070)$ \\
\hline \multirow[t]{2}{*}{ Is self-initiated } & -0.065 & 13.94 & 0.149 & -0.126 & 13.26 & \\
\hline & $(0.199)$ & $(1,133)$ & $(0.434)$ & $(0.697)$ & $(817.0)$ & \\
\hline \multirow[t]{2}{*}{ Located in Addis Ababa } & $0.074^{\star \star \star}$ & $1.565^{\star \star \star}$ & $0.764^{\star \star \star}$ & $0.586^{\star \star \star}$ & -0.032 & $-0.223^{\star \star \star}$ \\
\hline & $(0.015)$ & $(0.107)$ & $(0.030)$ & $(0.060)$ & $(0.110)$ & $(0.066)$ \\
\hline \multirow[t]{2}{*}{ Is managed professionally } & -0.007 & $0.962^{\star \star \star}$ & $0.241 * \star \star$ & $-0.356 \star \star$ & -0.107 & 0.228 \\
\hline & $(0.040)$ & $(0.174)$ & $(0.049)$ & $(0.155)$ & $(0.255)$ & $(0.157)$ \\
\hline \multirow[t]{2}{*}{ Size (lagged by one year) } & $0.010 * * *$ & $0.063^{\star \star \star}$ & $0.012^{\star \star \star}$ & $0.019 * \star \star$ & $0.020 * \star \star$ & $0.011^{\star \star \star}$ \\
\hline & $(0.001)$ & $(0.004)$ & $(0.002)$ & $(0.004)$ & $(0.001)$ & $(0.003)$ \\
\hline \multirow[t]{2}{*}{ Is patient } & 0.043 & 0.151 & $0.115^{\star \star \star}$ & $0.427 * \star \star$ & -0.179 & 0.081 \\
\hline & $(0.027)$ & $(0.151)$ & $(0.039)$ & $(0.115)$ & $(0.207)$ & $(0.081)$ \\
\hline \multirow[t]{2}{*}{ Is risk-taker } & $0.059 * * *$ & 0.056 & $0.096 * \star \star$ & -0.003 & -0.099 & $0.108^{\star \star}$ \\
\hline & $(0.015)$ & $(0.090)$ & $(0.023)$ & $(0.062)$ & $(0.111)$ & $(0.052)$ \\
\hline \multirow[t]{2}{*}{ Cognitive test score } & $0.035^{\star * \star}$ & $0.083^{\star \star \star}$ & $0.020 * *$ & $0.162^{\star \star *}$ & $0.102^{\star \star \star}$ & 0.005 \\
\hline & $(0.005)$ & $(0.030)$ & $(0.008)$ & $(0.021)$ & $(0.036)$ & $(0.021)$ \\
\hline Controls (sector \& ethnic) & Yes & Yes & Yes & Yes & Yes & Yes \\
\hline \multirow[t]{2}{*}{ Constant } & $6.906 * \star \star$ & -19.63 & 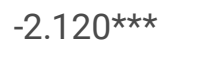 & -1.430 & -16.22 & 0.356 \\
\hline & $(0.255)$ & $(1,133)$ & $(0.493)$ & $(0.943)$ & $(817.0)$ & $(0.493)$ \\
\hline Number of observations & 7,148 & 7,922 & 7,922 & 7,922 & 7,890 & 656 \\
\hline \multicolumn{7}{|c|}{$\begin{array}{l}\text { Notes }(1):{ }^{* \star} p<0.01,{ }^{* \star} p<0.05, * \\
\text { parentheses are standard errors. }\end{array}$} \\
\hline \multicolumn{7}{|c|}{ Notes (2): Coefficients for logistic regression are in log-odds units. } \\
\hline \multicolumn{7}{|c|}{ Source: ESBDE Baseline Survey, 2017} \\
\hline
\end{tabular}




\begin{tabular}{|c|c|c|c|c|c|c|}
\hline \multirow[t]{3}{*}{ VARIABLES } & \multicolumn{3}{|c|}{ Wage and contract variables } & \multicolumn{3}{|c|}{ Health and occupational safety variables } \\
\hline & $\ln$ (wage) & $\begin{array}{l}\text { Written } \\
\text { contract } \\
\text { (binary) }\end{array}$ & $\begin{array}{l}\text { Permanent } \\
\text { workers } \\
\text { (Proportion) }\end{array}$ & $\begin{array}{l}\text { PPCE } \\
\text { (binary) }\end{array}$ & $\begin{array}{l}\text { Safety } \\
\text { training } \\
\text { (binary) }\end{array}$ & $\begin{array}{l}\text { In(number of work } \\
\text { related accidents) }\end{array}$ \\
\hline & OLS (1) & $\begin{array}{l}\text { Logistic } \\
\text { (2) }\end{array}$ & Tobit (4) & $\begin{array}{l}\text { Logistic } \\
\text { (5) }\end{array}$ & $\begin{array}{l}\text { Logistic } \\
(6)\end{array}$ & OLS (7) \\
\hline & & 0.28 & & & & 0.15 \\
\hline
\end{tabular}

$\begin{array}{lllll}\text { R-squared/ Pseudo R- } & 0.21 & 0.24 & 0.15 & 0.20\end{array}$ squared

Notes (1): *** $p<0.01, * \star p<0.05, * p<0.1$ are significance levels at $1,5 \& 10$ percent respectively. And numbers in parentheses are standard errors.

Notes (2): Coefficients for logistic regression are in log-odds units.

Source: ESBDE Baseline Survey, 2017

Likewise, years of management experience, which can be measured by variables such as years of operation of the firm or years of self-employment experience shows positive and highly significant effect on the job quality indicators, including contract security, and occupational safety measures. Entrepreneurs who have more years of management experience (measured by years of self-employment experience and years of operation) tend to offer contract security and provide all the necessary personal protective clothing and equipment (PPCE), and train their workers on occupational safety measures (see Table 10 columns 1, 2, 4,5 and 6).

Overall, the effects of human capital (which is measured by years of schooling, vocational training and English language skill) and the effects of managerial experience of the entrepreneur (which is measured by self-employment experience or years of operation by the firm) strongly support hypothesis 1 .

Consistent with hypothesis 2, Table 10 similarly presents the effects of enterprise size on the defined job quality indicators. Enterprise size (measured by lagged employment) tends to have stronger and significant positive effects on wages and contract, and health and occupational safety indicators. We use lagged employment size because if we are using current size as a regressor, we might want to be careful about endogeneity due to omitted variable bias. Note that size itself is an outcome variable. For example, larger firms could pay higher wages because they are more productive, but at the same time, they could become larger because of higher productivity, a relationship that we can neither observe not explicitly control for.

We could partly mitigate this problem by using lagged or initial size in place of current size. Thus, as postulated by hypothesis two, enterprises that operate on a larger scale tend to offer higher wages and better contract security, health and occupational safety measures. 
An additional finding is that enterprise location also matters. Enterprises that are located in Addis Ababa tend to create better quality jobs for their workers. The result on enterprise location, measured by a dummy variable equal to 1 if the enterprise is located in Addis Ababa and 0 otherwise, show a positive and highly significant effect on wages, contract stability, health and occupational indicators. This result could be related to hypothesis 1 and 2 in two ways. First, Addis Ababa tends to be a big market but also with stiff competition and this might put pressure on entrepreneurs to invest more in their human capital. Second, Addis Ababa might constitute migrant entrepreneurs, who are likely to be better educated, operate large businesses and risk-takers who see better opportunities in Addis Ababa.

We also tried to show if there is difference between enterprises that are managed professionally (by recruited managers) and enterprises that are managed by family members. Professionally managed enterprises are found to better in terms of providing written contracts to their workers and employing higher proportion of permanent workers relative to family managed enterprises.

\section{Conclusions And Implications}

Micro and small firms employ a large share of workers in developing countries. The same story holds for Ethiopia, where a great bulk of activities that take place in the informal sector, which mainly constitute micro and small enterprise, absorb as large as $70 \%$ of the labor force in urban areas. Consequently, the MSE sector receives massive program support. The assumption is that it will reduce urban poverty by creating as many jobs as possible. However, the creation of new jobs is in itself not sufficient. Whether the new jobs lift working people out of poverty or not is a major issue that needs to be discussed. Poverty will only be reduced to the extent that earnings are sufficient to cover basic necessities. Evidence suggests that the majority of current jobs in developing countries do not lift people out of poverty. Thus, in order to reduce poverty, developing countries do not just need more jobs; what are needed more importantly are quality jobs (i.e., jobs that pay better and have decent working conditions).

To this end, it may be policy relevant to differentiate those that create productive jobs from those that fail to create decent jobs in terms of their characteristics, attributes and strategies. Using a large dataset from a large representative sample survey of microenterprises and a census of small businesses in the 10 largest cities, we studied what entrepreneurial characteristics and attributes contribute to quality job creation in the micro and small enterprises (MSE) sector in Ethiopia. We measure job quality by two groups of indicators - wage and contract variables, and health and occupational safety variables.

At least three key findings have emerged from analysis. First, we find that micro and small enterprises that create productive (quality) jobs tend to be operated by highly educated entrepreneurs. Second, we found that micro and small enterprises that create productive (quality) jobs tend to be operated by highly experienced entrepreneurs. The first and second findings combined interestingly highlight the role of human capital in quality job creation and poverty reduction. Third, micro and small enterprises that create productive (quality) jobs tend to be larger in size and are managed professionally (i.e., by recruited managers).

The policy implication of our study is that the MSE support programs in Ethiopia tend to be generic and provide less incentive for firms to create quality jobs. They do not take into account the diverse nature of the sector. This kind of support program does not create the necessary incentives for enterprises to create productive jobs. The system seems to reward quantity and largely disregards quality. This will have its own implications in reducing poverty, especially in reducing the number of working poor. We think that our study would support first in bringing this issue to the attention of policy makers and second by identifying the key entrepreneurial qualities and strategies that help and drive productive job employment creation, and use this information to explore if differentiated and more tailored support programs could be adopted.

\section{Declarations}

Page 19/22 


\section{(a) Ethical approval and consent to participate}

All procedures performed in studies involving human participants were in accordance with the ethical standards of our research institute and the national research committee and with the 1964 Helsinki declaration and its later amendments or comparable ethical standards. We also confirm that we obtained informed consent from all individual participants included in the study.

\section{(b) Consent for publication}

The authors confirm that human research participants provided informed consent for publication of the research report a journal publication.

\section{(c) Availability of data and materials}

The datasets generated during and/or analyzed during this study are available from the corresponding author on reasonable request.

\section{(d) Competing interests}

We know of no conflicts of interest associated with this publication, and there has been no significant financial support for this work that could have influenced its outcome.

\section{(e) Funding}

The author(s) received no financial support for the research, authorship, and/or publication of this article.

\section{(f) Authors contribution}

I declare that this manuscript is original, has not been published before and is not currently being considered for publication elsewhere. As a corresponding Author, I confirm that I have read and approved the manuscript.

\begin{tabular}{|llll|}
\hline S.N & Author full name & Email ID & Contribution of author \\
\hline 2 & $\begin{array}{l}\text { Berihu Assefa } \\
\text { Gebrehiwot }\end{array}$ & berihuua86@gmail.com & $\begin{array}{l}\text { The author has directly participated in the planning, execution, } \\
\text { and analysis of this study }\end{array}$ \\
\hline
\end{tabular}

\section{(g) Acknowledgements}

We would like to acknowledge the technical help, including editorial works, we received from the Ethiopian Development Research Institute.

\section{(h) Author's information}

Berihu Assefa Gebrehiwot

Senior Researcher

Industrial Development Center

Ethiopian Development Research Institute (EDRI)

Email: berihuua86@gmail.com or berihu.assefa@psi.gov.et

\section{Bibliography}


1. Amossé, T., Kalugina, E.: (2010). Work quality indicators and job dynamics: is there a trade-off? A micro-econometric analysis on 10 European countries. XXVIII Journées de Microéconomie Appliquée, Working Paper

2. Assefa, B., Zerfu, A., Tekle, B.: Identifying Key Success Factors and Constraints of Ethiopia's MSE Development: An Exploratory Research. Ethiopian Development Research Institute, Addis Ababa (2014)

3. Ayyagari, M., Demirguc-Kunt, A., Maksimovic, V.: (2011). Small vs. young firms across the world: contribution to employment, job creation, and growth.

4. Barney, J.B.: The resource-based theory of the firm. Organization science 7(5), 469-469 (1996)

5. Becker, G.S.: (1962). Investment in human capital: A theoretical analysis.. Journal of political economy, 9-49

6. Birch, D.L.: (1979). The job generation process. MIT program on neighborhood and regional change

7. Birch, D., Medoff, J.: (1994). Gazelles. Labor markets, employment policy and job creation

8. Brown, A., Charlwood, A., Forde, C., Spencer, D.: (2007). Job quality and the economics of new labor: a critical appraisal using subjective survey data. Cambridge Journal of Economics, 941-971

9. Brown, C., Medoff, J.: The employer size-wage effect. Journal of political Economy 97(5), 1027-1059 (1989)

10. Cazes, S., Hijzen, A., Saintmartin, A.: (2015). Measuring and assessing job quality: the OECD job quality framework. Paris: OECD Social, Employment and Migration Working Papers No 174

11. Chen, S., Ravallion, M.: The developing world is poorer than we thought, but no less successful in the fight against poverty. Q. J. Econ. 125(4), 1577-1625 (2010)

12. Clark, A.E.: What really matters in a job? Hedonic measurement using quit data. Labour economics 8(2), 223-242 (2001)

13. Crespo, N., Simoes, N., Pinto, J.C.: (2017). Determinant factors of job quality in Europe. Argumenta Oeconomica, 15-40

14. CSA. (2016). Statistical Report on the 2016 Urban Employment Unemployment Survey. Addis Ababa

15. Davoine, L., Erhel, C., Guergoat-Lariviere, M.: Monitoring quality in work: European Employment Strategy indicators and beyond. Int. Labour Rev. 147(2-3), 163-198 (2008)

16. De Bustillo, R.M., Fernández-Macías, E., Antón, J.I., Esteve, F.: Measuring more than money: The social economics of job quality. Edward Elgar Publishing (2011a)

17. De Bustillo, R., Fernández-Macías, E., Esteve, F., Antón, J.: (2011b). E pluribus unum? A critical survey of job quality indicators. Socio-Economic Review, 447-475

18. Deijl, C., de Kok, J., Essen, V.: Is small still beautiful? Literature review of recent empirical evidence on the contribution of SMEs to employment creation. Deutsche Gesellschaft für Internationale Zusammenarbeit (GIZ) GmbH (2013)

19. Demoussis, M., Giannakopoulos, N.: Exploring job satisfaction in private and public employment: empirical evidence from Greece. Labour 21(2), 333-359 (2007)

20. Erhel, C., Guergoat-Larivière, M.: Job quality and labour market performance. Centre for European Policy Studies Working Document No. 3 (2010)

21. FeMSEDA: Micro and Small Enterprises Development Strategy. FDRE, Addis Ababa (2011)

22. Green, F.: Demanding work: The paradox of job quality in the affluent economy. Princeton University Press, Princeton (2006)

23. Hauff, S., Kirchner, S.: Cross-national differences and trends in job quality. A literature review and research agenda. Diskussionspapiere des Schwerpunktes Unternehmensführung am Fachbereich BWL der Universität Hamburg.

Fachbereich BWL der Unive (2014)

24. Henrekson, M., Johansson, D.: Gazelles as job creators: a survey and interpretation of the evidence. Small Bus. Econ. 35(2), 227-244 (2010)

25. Holman, D.: Job types and job quality in Europe. Hum. Relat. 66(4), 475-502 (2013)

Page 21/22 
26. Horowitz, J.: Dimensions of Job Quality, Mechanisms, and Subjective Well-Being in the United States. Sociol. Forum 31(2), 419-440 (2016)

27. ILO: Understanding deficits of productive employment and setting targets: a methodological guide. ILO, Geneva (2012)

28. ILO: World Employment and Social Outlook: The Changing Nature of Jobs. ILO, Geneva (2015)

29. IMF-ILO. (2010). The challenges of growth, employment and social cohesion. Oslo

30. Jovanovic, B.: Job matching and the theory of turnover. J. Polit. Econ. 87, 972-990 (1979)

31. Kalleberg, A.L., Reskin, B.F., Hudson, K.: (2000). Bad jobs in America: Standard and nonstandard employment relations and job quality in the United States. American sociological review, 256-278

32. Krueger, A.B., Summers, L.H.: (1988). Efficiency wages and the inter-industry wage structure. Econometrica: Journal of the Econometric Society, 259-293

33. Layard, R.: Happiness. Lessons from a New Science. Allen Lane, London (2005)

34. Leschke, J., Watt, A.: (2008). Job quality in Europe. Brussles: ETUI-REHS Research department working paper 2008.07

35. Levanon, A., England, P., Allison, P.: Occupational feminization and pay: Assessing causal dynamics using 1950-2000 US census data. Soc. Forces 88(2), 865-891 (2009)

36. Long, J.S.: Regression Models for Categorical and Limited Dependent Variables. SAGE (1997)

37. Meller, P., Marfan, M.: Small and large industry: employment generation, linkages, and key sectors. Econ. Dev. Cult. Change 29(2), 263-274 (1981)

38. Muhlau, P.: (2011). Gender inequality and job quality in Europe. Management Revue, 114-131

39. Mumford, K., Smith, P.N.: (2004). Job tenure in Britain: Employee characteristics versus workplace effects. Economica, 275-297

40. Oi, W.Y., Idson, T.L.: (1999). Firm size and wages. Handbook of labor economics(3), 2165-2214

41. Somavia, J.: (1999). Decent Work. Report of the Director-General: 87th Session of the International Labour Conference. Geneva: International Labour Office

42. Stier, H., Yaish, M.: Occupational segregation and gender inequality in job quality: a multi-level approach. Work, employment and society 28(2), 225-246 (2014)

43. Tangian, A.: Decent work: indexing European working conditions and imposing workplace tax. Transfer. European Review of Labour and Research 15(3-4), 527-556 (2009)

44. WB. (2016). World Bank Group. 2016. Poverty and Shared Prosperity 2016: Taking on Inequality. https://openknowledge.worldbank.org/handle/10986/25078 License: CC BY 3.0 IGO. Washington, DC:: World Bank

45. Westover, J.H.: A cross-national comparative analysis of job quality and perceived worker satisfaction: From post and neo-Fordist perspectives. International Journal of Economics and Management Sciences 2(1), 13-24 (2012) 